\title{
A 90-Day Oral Toxicity of Hydroethanolic Root Extract of Carissa spinarum in Wistar Rats
}

\author{
Komlan M. Dossou-Yovo $\mathbb{D}^{1},{ }^{1}$ Aboudoulatif Diallo ${ }^{D},{ }^{2}$ Povi Lawson-Evi, ${ }^{1}$ \\ Yendubé T. Kantati, ${ }^{1}$ Tchin Darré, ${ }^{3}$ Batomayena Bakoma, ${ }^{2}$ and Kwashie Eklu-Gadégbéku ${ }^{1}$ \\ ${ }^{1}$ Laboratory of Physiology and Pharmacology, Faculty of Sciences, University of Lome, Lome, Togo \\ ${ }^{2}$ Laboratory of Toxicology, Faculty of Health Sciences, University of Lome, Lome, Togo \\ ${ }^{3}$ Laboratory of Pathological Anatomy and Cytology, Faculty of Health Sciences, University of Lome, Lome, Togo
}

Correspondence should be addressed to Komlan M. Dossou-Yovo; eugyodossou@gmail.com

Received 1 March 2021; Revised 8 April 2021; Accepted 12 April 2021; Published 20 April 2021

Academic Editor: Zongming Ren

Copyright (C) 2021 Komlan M. Dossou-Yovo et al. This is an open access article distributed under the Creative Commons Attribution License, which permits unrestricted use, distribution, and reproduction in any medium, provided the original work is properly cited.

\begin{abstract}
Background. Herbal medication is a worldwide and ancient practice, mostly in developing countries, where a large part of the population is involved in this practice. Hence, studies must be conducted to evaluate their safety and efficiency to avoid or prevent toxicological risks due to their usage. In Togo, Carissa spinarum is a medicinal plant belonging to Apocynaceae family, used as an aphrodisiac or to heal some ailments including malaria, sickle cell anemia, hypertension, pain, and asthma. Notwithstanding its several ethnomedicinal benefits, just a few toxicological data associated with its chronic use are available. Objective. Therefore, this study aims to assess the toxicity of an ethanolic root extract of Carissa spinarum in Wistar rats. Methods. The 90-day oral toxicity process following OECD TG 408 guidelines is used. Male Wistar rats received Carissa spinarum root hydroethanolic extract at 500 and $1000 \mathrm{mg} / \mathrm{kg}$ for 90 days by oral gavage. Body weight changes, hematological and blood biochemical parameters, organ weight changes, malondialdehyde as a lipoperoxidation marker expressed according to tissue proteins, and histopathology of vital organs were assessed. Results. No signs of toxicity or mortality were observed during the 90 days experiment. Hematological parameters have not shown any treatment-related abnormalities. According to biochemical parameters, an increase in the chloride ion level was observed at $1000 \mathrm{mg} / \mathrm{kg}(p<0.01)$. There was no significant difference between the treated groups and the control group concerning the malondialdehyde concentration, body weight, and organ relative weight. No changes in necropsy and histopathology of vital organs associated with extract treatment were observed. Conclusion. The results indicated that an ethanolic root extract of Carissa spinarum does not cause adverse effects, which can lead to Wistar rats' death after 90-day oral administration at 500 and $1000 \mathrm{mg}$.
\end{abstract}

\section{Introduction}

Carissa spinarum is a spiny plant of Apocynaceae family traditionally used to heal many ailments such as sickle cell anemia, malaria, hypertension, headache, pain, asthma, and sexual weakness [1-3], particularly in Togo and in the West African region in general. Herbal medicinal healing is a worldwide and ancient practice, mostly in developing countries, where a large part of the population is involved in this practice [4]. In some south Saharan countries, this practice is maintained [5], whereas in developed countries, we observe an increase in the use of medicinal plants [6-8]. This interest for medicinal plants may be explained by many reasons such as the fact that plants are the main source of new bioactive molecules for pharmaceutical industries [9-11]. Other reasons are that plants are considered inoffensive to people $[12,13]$ or are simply the only or the main health care product accessible for some people [14]. This practice can be due also to financial constraints $[13,15]$. Despite these numerous reasons that lead to herbal medications, caution must be taken in plant usage due to side effects such as liver damage or respiratory failure associated 
with continuous use of some plants [16]. Previous studies reported that Carissa spinarum has some pharmacological properties such as anticonvulsant effect [17], diuretic effect [1], and analgesic effect [2]. It is reported to contain some chemical groups such as tannins, saponins, flavonoids, and cardenolides [18]. Plant cardiac glycosides can be involved in case of poisoning by its action on $\mathrm{Na}^{+} / \mathrm{K}^{+}$pump [19]. This can lead to severe side effects such as arrhythmias, bradycardia, and hypotension [13], which sometimes can be fatal $[20,21]$. Some toxicological data available on the root hydroethanolic extract reported that its lethal dose 50 (LD50) is above $5 \mathrm{mg} / \mathrm{kg}$ and it may be relatively safe for 28 day oral repeated-dose administration in Wistar rats [18]. Nevertheless, there are no toxicological data on the chronic use of Carissa spinarum roots. This information may be important mainly in the use of Carissa spinarum in chronic diseases, healing, or life-treating ailments such as erectile dysfunction, diabetes, and hypertension. This study aims, hence, to evaluate the long-term toxicity of hydroethanolic root extract of Carissa spinarum by 90 -day oral administration in Wistar rats to have additional toxicological data on Carissa spinarum root use.

\section{Materials and Methods}

2.1. Collection and Extraction of Plant Materials. Carissa spinarum roots were collected at Noépé $\left(6^{\circ} 17^{\prime} 38^{\prime \prime} \mathrm{N}\right.$ and $1^{\circ} 1^{\prime} 19^{\prime \prime} \mathrm{E}$, Togo) and were identified at the Botany and Ecology Department of the University of Lomé. The specimen was kept at the herbarium of University of Lomé under NTOGO15579. The roots were cleaned and dried under climatization $\left(20^{\circ} \mathrm{C}\right)$ in the Animal Physiology Laboratory of University of Lomé. Then, the dried and pulverized roots were soaked in mixed ethanol-water (50-50) for $72 \mathrm{~h}$ under automatic agitation on an orbital shaker (IKA KS 501Orbital Digital Platform Shaker). After double filtration with cotton and Whatman paper, the filtrate was evaporated at $45^{\circ} \mathrm{C}$ using a rotating evaporator (IKA RV 10 Digital).

2.2. Animals. Male Wistar rats weighting $161.05 \mathrm{~g}$ were used for the experimentations. They were provided by the Animal Physiology Department and were acclimated at least one week prior the debut of the manipulations. The animals were fed with rodent standard diets and water ad libitum. Animals before and during the study were kept at $22^{\circ} \mathrm{C} \pm 2^{\circ} \mathrm{C}$ with a relative humidity level of $40 \%$ and the photoperiod was 12 -h light and 12-h dark. Animal care and handling were conformed to accepted guidelines $[22,23]$. Ethical approval was obtained from the institutional Ethical Committee for Teaching and Research under the number (ref no. CNCBCEER 2801/2010).

2.3. Experimental Design. Repeated-dose oral toxicity of 90 days was performed according to OECD guidelines 408 [24]. Doses were assigned based on previous toxicological studies [19], and as not limited by physical-chemical nature of the extract, the highest dose was chosen with the aim to induce toxicity, not death or severe toxicity as recommended by
OECD guidelines (TG 408). Animals were divided into three groups of 8 each. The first group (group 1) received distilled water and served as the control group. The second (group 2) and the third (group 3) groups received, respectively, $500 \mathrm{mg} / \mathrm{kg}$ and $1000 \mathrm{mg} / \mathrm{kg}$ body weight of Carissa spinarum root hydroalcoholic extract. The extract was administered daily for 90 days at the same time, and the animals were observed at least twice daily for morbidity and mortality. The body weights were recorded every day.

2.4. Hematological and Biochemical Parameters. On the 91st day after $12 \mathrm{~h}$ of fasting, the rats were anesthetized by ether. Blood samples were collected from retro-orbital sinus in dry tubes for biochemical analyses and in EDTA tubes for hematological analyses. Biochemical parameters such as alanine aminotransferase (ALAT), aspartate aminotransferase (ASAT), alkaline phosphatase, creatinine and glucose, triglyceride, and phosphocreatine kinase (CPK) were assessed. Dosage of some ion levels in serum like sodium, chloride, potassium, and calcium was also assessed. Hematological parameters achieved were white blood cell count (WBC), red blood cell count (RBC), hematocrit (HCT), hemoglobin (HB), mean corpuscular hemoglobin concentration (MCHC), mean corpuscular hemoglobin $(\mathrm{MCH})$, platelet count (PLT), and mean corpuscular volume (MCV).

2.5. Gross Observation and Organ Weights. After exsanguination, each rat was euthanized by ether and then dissected for macroscopic examination. The liver, kidney, testicles, heart, and spleen were isolated and weighted. Relative organ weight was calculated based on the following equation: relative weight $=$ (weight of the organ/body weight of the animal on sacrifice day) $\times 100$. Samples were thereafter fixed in $10 \%$ formalin solution to achieve histopathological sections.

2.6. Lipid Peroxidation Test and Total Protein Assay. Lipid peroxidation test and protein assay were carried out on heart, liver, and kidney according, respectively, to GérardMonnier et al. $[25,26]$ using the 1-methyl-2-phenylindole and Bradford method [27, 28]. Malondialdehyde (MDA) concentration was expressed in $\mathrm{nM} / \mathrm{mg}$ of protein.

2.6.1. Lipid Peroxidation Test. The removed organs were rinsed in $9 \mathrm{~g} / \mathrm{L} \mathrm{NaCl}$, crushed in a glass pot in the presence of Tris- $\mathrm{HCl}$ buffer $(10 \mathrm{mM}$; pH 7.5). The reaction solution contained $650 \mu \mathrm{L}$ of 1-methyl-2-phenylindole activated by acetonitrile, $250 \mu \mathrm{L}$ of MDA or organ homogenate, $150 \mu \mathrm{L}$ of the $\mathrm{HCl}$ solution with the concentration of $12 \mathrm{~N}$, and $10 \mu \mathrm{L}$ of BHT (butylated hydroxy toluene) solution at a concentration of $0.1 \mathrm{M}$. The tubes were incubated at $45^{\circ} \mathrm{C}$ for 1 hour. The tubes were then centrifuged at $1881.59 \mathrm{~g}$ per minute for 10 minutes. The absorbance was read at the wavelength of $586 \mathrm{~nm}$. For quantitation, a calibration curve of an accurately prepared standard MDA solution was done. 
2.6.2. Protein Assay. The Bradford assay is based on the use of Coomassie blue (G-250). The cationic form (under acid conditions) of Coomassie blue is red, whereas the anionic form is blue. The Bradford reagent is primarily protonated and red as it is an acidified solution. Upon to protein binding, the Coomassie blue dye becomes unprotonated and blue. The change in the color is measured spectroscopically at $595 \mathrm{~nm}$.

The supernatant obtained after tissue extraction was diluted at 1/20 in phosphate buffer and homogenized. Five microliters of the test sample or blank were collected in triplicate in tubes, and $250 \mu \mathrm{L}$ of Bradford reagent were added in each tube. After $30 \mathrm{~min}$ of incubation at room temperature, the samples were read at $595 \mathrm{~nm}$.

2.7. Statistical Analysis. Results were expressed in mean\pm standard error of the mean (SEM). Statistical analysis was performed by analysis of variance (ANOVA) with Tukey's test to evaluate the difference between two groups. Values of $p<0.05$ were considered significant. The InStat statistical package (GraphPad Prism 6.02) was used to carry out all statistical analyses.

\section{Results}

3.1. Clinical Observations. The 90-day oral administration of the extract did not provoke behavioral changes in the treated groups. No death or adverse effects were observed during the experiment.

3.2. Body Weight and Organ Ratio Weight. Our results have shown that the extract did not induce any modification of the mean weight of rats after 90 days of administration (Table 1). Rats' organ ratio weight after 90 days of experiment did not show significant differences between groups (Table 2).

3.3. Hematological Parameters. No abnormality was observed on hematological parameters after 90 days of administration of C. spinarum (Table 3).

3.4. Biochemical Parameters. For biochemical parameters, no significant changes were observed. However, the electrolytes have presented some variations, principally a significant increase of chloride ions at $1000 \mathrm{mg} / \mathrm{kg}$ (Table 4).

3.5. Gross Observation. No abnormalities were detected after gross examination of organs between the treated and control groups. No inflammation, internal bleeding, lesions, or deformity was observed in the liver, kidney, testis, spleen, and heart in treated rats compared with the control group following the administration of Carissa spinarum root extract at different doses for 90 days of treatment.

The histological sections of heart, liver, kidney, testis, and spleen have not shown abnormalities in the architectural structure of organs in any group (data were not shown).
TABLE 1: Effect of the hydroethanolic extract of Carissa spinarum root on rats' body weight.

\begin{tabular}{lccc}
\hline Weeks & \multicolumn{2}{c}{$\begin{array}{c}\text { Hydroethanolic root extract } \\
\text { of C. spinarum }\end{array}$} \\
& Control & $500 \mathrm{mg} / \mathrm{kg}$ & $1000 \mathrm{mg} / \mathrm{kg}$ \\
\hline 0 & $159.58 \pm 8.51$ & $163.16 \pm 7.48$ & $160.41 \pm 7.73$ \\
1 & $160.33 \pm 7.49$ & $158.75 \pm 7.65$ & $162.91 \pm 5.14$ \\
2 & $160.16 \pm 8.41$ & $164.50 \pm 7.30$ & $164.58 \pm 5.37$ \\
3 & $163.00 \pm 8.36$ & $165.91 \pm 8.16$ & $165.00 \pm 5.73$ \\
4 & $170.91 \pm 8.82$ & $171.33 \pm 8.46$ & $170.00 \pm 6.25$ \\
5 & $172.83 \pm 8.35$ & $175.09 \pm 7.78$ & $171.63 \pm 6.07$ \\
6 & $178.83 \pm 7.87$ & $180.54 \pm 8.90$ & $176.60 \pm 7.48$ \\
7 & $175.58 \pm 7.69$ & $183.00 \pm 9.18$ & $176.30 \pm 6.89$ \\
8 & $175.41 \pm 7.67$ & $186.00 \pm 9.10$ & $179.40 \pm 6.54$ \\
9 & $175.50 \pm 7.72$ & $178.88 \pm 7.84$ & $178.70 \pm 6.50$ \\
10 & $175.45 \pm 8.55$ & $179.62 \pm 7.99$ & $179.00 \pm 6.20$ \\
11 & $186.50 \pm 9.97$ & $179.87 \pm 9.17$ & $177.50 \pm 5.19$ \\
12 & $184.20 \pm 10.93$ & $189.66 \pm 8.44$ & $169.50 \pm 7.65$ \\
13 & $188.77 \pm 12.77$ & $194.00 \pm 11.26$ & $177.75 \pm 7.39$ \\
\hline
\end{tabular}

Each value is a mean \pm SEM, $n=8$.

TABLE 2: Effect of the hydroethanolic extract of Carissa spinarum root on organs relative weight.

\begin{tabular}{lccc}
\hline Organs & \multicolumn{2}{c}{$\begin{array}{c}\text { Hydroethanolic root extract } \\
\text { of C. spinarum }\end{array}$} \\
& Control & $500 \mathrm{mg} / \mathrm{kg}$ & $1000 \mathrm{mg} / \mathrm{kg}$ \\
\hline Liver & $3.043 \pm 0.147$ & $3.075 \pm 0.225$ & $2.892 \pm 0.197$ \\
Heart & $0.462 \pm 0.032$ & $0.442 \pm 0.037$ & $0.418 \pm 0.017$ \\
Kidney & $0.626 \pm 0.021$ & $0.665 \pm 0.027$ & $0.630 \pm 0.028$ \\
Spleen & $0.293 \pm 0.020$ & $0.266 \pm 0.036$ & $0.284 \pm 0.028$ \\
Testis & $1.078 \pm 0.051$ & $1.198 \pm 0.201$ & $1.014 \pm 0.102$ \\
\hline
\end{tabular}

Each value is a mean \pm SEM, $n=8$.

TABLE 3: Effect of the hydroethanolic extract of Carissa spinarum root on hematological parameters.

\begin{tabular}{lccc}
\hline \multirow{4}{*}{ Parameters } & \multicolumn{3}{c}{$\begin{array}{c}\text { Hydroethanolic root } \\
\text { extract of C. spinarum }\end{array}$} \\
& Control & $500 \mathrm{mg} / \mathrm{kg}$ & $1000 \mathrm{mg} / \mathrm{kg}$ \\
\hline $\mathrm{WBC}, \times 10^{3} / \mu \mathrm{L}$ & $2.18 \pm 0.32$ & $3.94 \pm 0.68$ & $3.31 \pm 0.54$ \\
$\mathrm{RBC}, \times 10^{6} / \mu \mathrm{L}$ & $5.90 \pm 0.14$ & $5.75 \pm 0.29$ & $5.93 \pm 0.14$ \\
$\mathrm{HB}, \mathrm{g} / \mathrm{dL}$ & $12.17 \pm 0.33$ & $11.88 \pm 0.72$ & $12.13 \pm 0.32$ \\
$\mathrm{HCT}, \%$ & $31.53 \pm 1.39$ & $31.28 \pm 1.23$ & $30.53 \pm 0.81$ \\
$\mathrm{VGM}, \mathrm{fL}$ & $51.76 \pm 1.05$ & $52.85 \pm 1.07$ & $51.42 \pm 1.05$ \\
$\mathrm{MCH}, \mathrm{pg}$ & $20.58 \pm 0.15$ & $20.51 \pm 0.21$ & $20.45 \pm 0.23$ \\
$\mathrm{MCHC}, \mathrm{g} / \mathrm{dL}$ & $39.86 \pm 0.52$ & $40.87 \pm 0.68$ & $39.80 \pm 0.36$ \\
$\mathrm{PLT}, \times 10^{5} / \mu \mathrm{L}$ & $8.49 \pm 0.54$ & $8.20 \pm 0.43$ & $7.18 \pm 0.63$ \\
\hline
\end{tabular}

Each value is a mean \pm SEM, $n=8$.

3.6. Lipid Peroxidation and Protein Assay. The lipid peroxidation test in the heart, liver, and kidney has not shown significant differences of malondialdehyde (MDA) concentration between control and treated groups (Table 5).

\section{Discussion}

This study was conducted to evaluate the 90 -day oral toxicity of C. spinarum, a plant used for many purposes in Togo and 
TABLE 4: Effect of the hydroethanolic extract of Carissa spinarum root on biochemical parameters.

\begin{tabular}{lccc}
\hline & \multicolumn{3}{c}{$\begin{array}{c}\text { Hydroethanolic root extract of } \\
\text { Parameters }\end{array}$} \\
& Control & $500 \mathrm{mg} / \mathrm{kg}$ & $1000 \mathrm{mg} / \mathrm{kg}$ \\
\hline Glucose, mmol/L & $5.13 \pm 0.36$ & $5.10 \pm 0.34$ & $4.38 \pm 0.32$ \\
ALAT, UI/L & $40.91 \pm 5.72$ & $38.62 \pm 4.29$ & $38.95 \pm 5.47$ \\
ASAT, UI/L & $160.33 \pm 6.20$ & $174.35 \pm 9.04$ & $160.78 \pm 6.68$ \\
ALP, UI/L & $316.88 \pm 31.83$ & $352.67 \pm 35.70$ & $235.19 \pm 33.75$ \\
Urea, g/L & $0.49 \pm 0.03$ & $0.48 \pm 0.05$ & $0.41 \pm 0.02$ \\
Creatinine, g/dL & $4.29 \pm 0.33$ & $3.20 \pm 025$ & $3.50 \pm 0.21$ \\
CPK & $338.29 \pm 31.83$ & $339.39 \pm 46.82$ & $261.06 \pm 28.35$ \\
Triglycerides, g/L & $1.59 \pm 0.11$ & $1.75 \pm 0.16$ & $1.64 \pm 0.09$ \\
Sodium, mmol/L & $192.56 \pm 2.85$ & $173.93 \pm 11.86$ & $189.66 \pm 9.81$ \\
Potassium, & $2.08 \pm 0.14$ & $1.66 \pm 0.19$ & $1.84 \pm 0.18$ \\
mmol/L & & & \\
Chloride, mmol/ & $79.20 \pm 3.83$ & $87.23 \pm 2.48$ & $108.42 \pm 8.30^{* *}$ \\
L & & & \\
Calcium, mg/dL & $8.28 \pm 0.37$ & $7.11 \pm 0.44$ & $8.02 \pm 0.38$ \\
\hline
\end{tabular}

Each value is a mean \pm SEM, $n=8 .{ }^{* *} p<0.01$.

TABLE 5: Effect of the hydroethanolic extract of Carissa spinarum root on MDA concentration.

\begin{tabular}{lccc}
\hline & & \multicolumn{2}{c}{$\begin{array}{c}\text { Hydroethanolic root } \\
\text { extract of C. spinarum }\end{array}$} \\
& Control & $500 \mathrm{mg} / \mathrm{kg}$ & $1000 \mathrm{mg} / \mathrm{kg}$ \\
\hline $\begin{array}{l}\text { Heart, nM MDA/mg } \\
\text { protein }\end{array}$ & $0.65 \pm 0.17$ & $0.90 \pm 0.20$ & $1.08 \pm 0.20$ \\
$\begin{array}{l}\text { Liver, nM MDA/mg } \\
\text { protein }\end{array}$ & $0.67 \pm 0.05$ & $0.52 \pm 0.059$ & $0.61 \pm 0.04$ \\
$\begin{array}{l}\text { Kidney, nM MDA/mg } \\
\text { protein }\end{array}$ & $1.19 \pm 0.11$ & $1.54 \pm 0.14$ & $1.47 \pm 0.079$ \\
\hline
\end{tabular}

Each value is a mean \pm SEM, $n=8$.

the West African region mainly as an aphrodisiac [29]. Based on previous toxicological results [18], a limit test of 90-day oral toxicity test was performed at 500 and $1000 \mathrm{mg} / \mathrm{kg}$ according to OECD 408 guidelines. The C. spinarum hydroalcoholic root extract at 500 and $1000 \mathrm{mg} / \mathrm{kg}$ did not provoke toxic effects capable to lead treated rats to death or affect their behavior as no death or clinical abnormalities were observed.

Body weight reduction can be a sensitive and simple index of toxicity, and a 5\% reduction in body weight is considered an empirical predictor of pathological findings [30]. The body weight change of the treated group rats compared with the control group had not shown significant difference after 90 days of experiment. The organ relative weight is an indicator of hypertrophy or atrophy of organs [31]. It is a well-accepted indictor of chemical effects on organs [32]. The relative weight of organs such as heart, spleen, testis, liver, and kidney has not shown significant difference between the treated groups and the control. Additionally, histological data have not shown any structural abnormalities as all architectures of the studied organs were conserved over all groups. The extract at 500 and $1000 \mathrm{mg} / \mathrm{kg}$ did not induce adverse effects on the studied organs.
Another good toxicity predictor is blood cells, which are the first cells exposed to a toxic when it reaches the systemic circulation. Hence, red blood cells give a good prediction on the toxic potential of a molecule $[18,33]$. In our study, the hematological parameters of the treated groups have not shown significant difference when compared to the control group. The hydroalcoholic root extract of C. spinarum at 500 and $1000 \mathrm{mg} / \mathrm{kg}$ did not reveal toxic effects on blood cells [34]. The liver and kidney are key organs ensuring important role for the organism. The liver is the main organ involved in substance metabolism, and due to this, it is exposed to toxic effects. The kidney by its functional unit nephrons is involved in the excretion of waste substances and toxins in the body. Hence, a damage due to plant-related products or toxic substance ingestion by mechanisms such as tubular toxicity, crystal nephrotoxicity, or glomerular hemodynamic alterations can lead to loss of the kidney or death if appropriate medicinal therapy is not given to the patient [13]. Their exploration is therefore important in toxicity studies and can be based on some biomarker level dosage.

Located in hepatocytes, cytoplasm, and mitochondria (for ALAT), transaminases (ASAT, ALAT) associated to ALP and glucose which are found for the first in the biliary canaliculi and epithelial cells comprising the bile ducts are parameters to explore the liver toxicity $[35,36]$. ASAT and ALAT are considered leakage enzymes; thus, their augmentation in blood serum may be the result of hepatocellular or mitochondrial membrane alterations following liver injury. ALP on its own is considered a cholestatic induction enzyme and is "induced" for their elevation following obstruction to bile flow [37]. Our study did not show significant differences of these biomarkers when treated groups are compared to the control group. These results are close to histological data, which did not reveal any architectural or structural abnormalities of the concerned organs.

Renal functional exploration can be based on urea, creatinine, and electrolyte dosage. They are good markers of renal function. In our study, changes in urea and creatinine were not significant. It suggests that the extract did not cause renal dysfunction. However, a significant increase in chloride ion level at $1000 \mathrm{mg} / \mathrm{kg}$ suggested a misbalance in the serum chloride level, which can be a simple result of the diuretic activity of $C$. spinarum [1]. In that case, the loss of an important volume of diluted urine may explain this hyperchloremia $[3,38,39]$.

Malondialdehyde is an oxidative stress marker that results in the cell membrane disruption provoked by reactive oxidative stress attack on polyunsaturated fatty acids. Then, MDA is a product of lipid peroxidation. This lipoperoxidation derives aldehydes, which can damage the protein by forming covalent adducts. This process can lead to tissue destruction [40]. Oxidative stress is a process due to an imbalance between reactive oxygen species (ROS) and antioxidants. This process causes structural and functional damage in organs and then, it can lead to toxicity [41]. In our study, the MDA level was assessed in the heart, liver, and kidney. We did not observe significant differences according to MDA concentration when comparing control with treated groups. This result suggests that C. spinarum did not 
favor the oxidative process in the studied organs during the 90-day oral administration.

\section{Conclusion}

In this study, we have evaluated the 90-day oral toxicity of the hydroalcoholic extract of C. spinarum root. The results showed that at 500 and $1000 \mathrm{mg} / \mathrm{kg}$, C. spinarum hydroalcoholic root extract is relatively safe for oral administration to Wistar rats at 500 and $1000 \mathrm{mg} / \mathrm{kg}$. Nevertheless, more toxicological studies must be performed on key organs $e x$ vivo or in vitro to confirm its real safety for chronic use, mainly on the cardiovascular system, liver, and kidney, which are important organs of our body.

\section{Data Availability}

The data used to support the findings of this study are available from the corresponding author upon request.

\section{Conflicts of Interest}

The authors declare no conflicts of interest.

\section{References}

[1] T. Nedi, N. Mekonnen, and K. Urga, "Diuretic effect of the crude extracts of Carissa edulis in rats," Journal of Ethnopharmacology, vol. 95, no. 1, pp. 57-61, 2004.

[2] H. Ibrahim, E. M. Abdulrahman, M. Shok, N. Ilyas, K. Y. Musa, and I. Ukandu, "Comparative analgesic activity of the root bark, stem bark, leaves, fruits and seed of Carissa edulis Vahl (Apocynaceae)," African Journal of Biotechnology, vol. 6, no. 10, 2007.

[3] I. Ansari and D. T. Patil, "A brief review on phytochemical and pharmacological profile of Carissa spinarum L." Asian Journal of Pharmaceutical and Clinical Research, vol. 11, no. 9, pp. 12-18, 2018.

[4] J. C. Tilburt and T. J. Kaptchuk, "Herbal medicine research and global health, an ethical analysis," Bulletin of the World Health Organization, vol. 86, no. 8, pp. 577-656, 2008.

[5] I. A. Bello, G. I. Ndukwe, O. T. Audu, and J. D. Habila, "A bioactive flavonoid from Pavetta crassipes K. Schum," Organic and Medicinal Chemistry Letters, vol. 1, no. 1, p. 14, 2011.

[6] E. Roeder, "Medicinal plans in europe containing pyrrolizidine alkaloids," Pharmazie, vol. 50, no. 2, pp. 83-98, 1995.

[7] A. MacLennan, D. H. Wilson, and A. W. Taylor, "The escalating cost and prevalence of alternative medicine," Preventive Medicine, vol. 35, no. 2, pp. 166-173, 2002.

[8] P. M. Barnes, E. Powell-Griner, K. McFann, and R. L. Nahin, "Complementary and alternative medicine use among adults: United States, 2002," Seminars in Integrative Medicine, vol. 2, no. 2, pp. 54-71, 2004.

[9] D. J. Newman and G. M. Cragg, "Natural products as sources of new drugs over the last 25 years," Journal of Natural Products, vol. 70, no. 3, pp. 461-477, 2007.

[10] D. J. Newman and G. M. Cragg, "Natural products as sources of new drugs over the 30 years from 1981 to 2010," Journal of Natural Products, vol. 75, no. 3, pp. 311-335, 2012.

[11] D. J. Newman and G. M. Cragg, "Natural products as sources of new drugs from 1981 to 2014," Journal of Natural Products, vol. 79, no. 3, pp. 629-661, 2016.
[12] L. A. Alli, A. A. Adesokan, O. A. Salawu, and M. A. Akanji, "Toxicological studies of aqueous extract of Acacia nilotica root," Interdisciplinary Toxicology, vol. 8, no. 1, pp. 48-54, 2015.

[13] M. H. Farzaei, Z. Bayrami, F. Farzaei et al., "Poisoning by medical plants," Archives of Iranian Medicine, vol. 23, no. 2, pp. 117-127, 2020.

[14] M. Chan, WHO Strategy for Traditional Medicine for 2014-2023, World Health Organization, Geneva, Switzerland, 2014.

[15] R. H. Bannerman, J. Burton, and W. C. Chen, Traditional Medicine and Health Care Coverage: A Reader for Health Administrators and Practitioners, World Health Organization, Geneva, Switzerland, 1983.

[16] V. P. Kamboj, "Herbal medicine," Current Science, vol. 78, no. 1, pp. 35-39, 2000.

[17] J. Ya'u, A. H. Yaro, M. S. Abubakar, J. A. Anuka, and I. M. Hussaini, "Anticonvulsant activity of Carissa edulis (Vahl) (Apocynaceae) root bark extract," Journal of Ethnopharmacology, vol. 120, no. 2, pp. 255-258, 2008.

[18] K. M. Dossou-Yovo, A. Diallo, P. Lawson-Evi, T. Darré, B. Bakoma, and K. Eklu-Gadégbéku, "Cytotoxicity, acute, and subacute study of hydroalcoholic root extract of Carissa spinarum L. on wistar rats," Journal of Medicinal Food, 2020.

[19] C. Job, "A retrospective study of poisoning cases in Thrissur district of Kerala for the year 1995," JIST, vol. 5, no. 1, pp. 23-27, 2009.

[20] Centers for Disease Control and Prevention, "Deaths associated with a purported aphrodisiac-New York city," Morbidity and Mortality Weekly Report, vol. 44, no. 46, p. 853, 1995.

[21] M. Lopez Castillo, P. Sanchez Borque, J. M. Rubio Campal, and J. Farre Muncharaz, "4991Death by love stone, a dangerous aphrodisiac drug," European Heart Journal, vol. 38, no. 1, p. 1430, 2017.

[22] OECD: Organization for Economic Cooperative Development, Guidelines for the Testing of Chemicals/Section 4: Health Effects Test No. 423, Acute Oral toxicity-Acute Toxic Class Method Organization for Economic Cooperation and Development, Paris, France, 2002.

[23] OECD: Organization for Economic Cooperative Development, "Repeated dose oral toxicity test method," in OECD Guidelines for Testing of Chemicals, Organization for Economic Cooperation and Development, Paris, France, 2008.

[24] OECD: Organization for Economic Cooperative Development, "Repeated dose 90-day oral toxicity study in rodents," in OECD Guidelines for Testing of Chemicals, Section 4, Organization for Economic Cooperation and Development, Paris, France, 2018.

[25] D. Gérard-Monnier, I. Erdelmeier, K. Régnard, N. MozeHenry, J.-C. Yadan, and J. Chaudière, "Reactions of 1-methyl2-phenylindole with malondialdehyde and 4-hydroxyalkenals. Analytical applications to a colorimetric assay of lipid peroxidation," Chemical Research in Toxicology, vol. 11, no. 10, pp. 1176-1183, 1998.

[26] A. K. Patlolla, C. Barnes, C. Yedjou, V. R. Velma, and P. B. Tchounwou, "Oxidative stress, DNA damage, and antioxidant enzyme activity induced by hexavalent chromium in Sprague-Dawley rats," Environmental Toxicology, vol. 24, no. 1, pp. 66-73, 2009.

[27] M. M. Bradford, "A rapid and sensitive method for the quantitation of microgram quantities of protein utilizing the principle of protein-dye binding," Analytical Biochemistry, vol. 72, no. 1-2, pp. 248-254, 1976. 
[28] A. J. Ninfa, D. P. Ballou, and M. Benore, Fundamental Laboratory Approaches for Biochemistry and Biotechnology, Wiley, Hoboken, NJ, USA, 2008.

[29] I. A. Batcho, E. E. B. K. Ewédjè, H. Yédomonhan, and A. C. Adomou, "Diversity and endogenous knowledge of aphrodisiac plants in south and Central Benin," Research Square, 2020.

[30] A. V. Silva, U. Norinder, E. Liiv, B. Platzack, M. Öberg, and E. Törnqvist, "Associations between clinical signs and pathological findings in toxicity testing," ALTEX-Alternatives to Animal Experimentation, 2020.

[31] G. Amresh, P. N. Singh, and C. V. Rao, "Toxicological screening of traditional medicine Laghupatha (Cissampelos pareira) in experimental animals," Journal of Ethnopharmacology, vol. 116, no. 3, pp. 454-460, 2008.

[32] S. E. Lazic, E. Semenova, and D. P. Williams, "Determining organ weight toxicity with Bayesian causal models: improving on the analysis of relative organ weights," Scientific Reports, vol. 10 , no. 1 , pp. 1-12, 2020.

[33] S. Deyno, A. Abebe, M. A. Tola et al., "Acute and sub-acute toxicity of Echinops kebericho decoction in rats," $B M C$ Complementary Medicine and Therapies, vol. 20, no. 1, pp. 1-11, 2020.

[34] H. Olson, G. Betton, D. Robinson et al., "Concordance of the toxicity of pharmaceuticals in humans and in animals," Regulatory Toxicology and Pharmacology, vol. 32, no. 1, pp. 56-67, 2000.

[35] C. M. Corns, "Herbal remedies and clinical biochemistry," Annals of Clinical Biochemistry: International Journal of Laboratory Medicine, vol. 40, no. 5, pp. 489-507, 2003.

[36] M. H. Pittler and E. Ernst, "Systematic review: hepatotoxic events associated with herbal medicinal products," Alimentary Pharmacology \& Therapeutics, vol. 18, no. 5, pp. 451-471, 2003.

[37] S. K. Ramaiah, "A toxicologist guide to the diagnostic interpretation of hepatic biochemical parameters," Food and Chemical Toxicology, vol. 45, no. 9, pp. 1551-1557, 2007.

[38] V. L. Clark and J. A. Kruse, "Clinical methods: the history, physical, and laboratory examinations," JAMA, vol. 264, no. 21, pp. 2808-2809, 1990.

[39] C. A. Pfortmueller, D. Uehlinger, S. von Haehling, and J. C. Schefold, "Serum chloride levels in critical illness-the hidden story," Intensive Care Medicine Experimental, vol. 6, no. 1, p. 10, 2018.

[40] H. Cichoż-Lach and M. Agata, "Oxidative stress as a crucial factor in liver diseases," World Journal of Gastroenterology, vol. 20, no. 25, pp. 8082-8091, 2014.

[41] D. R. Janero, "Malondialdehyde and thiobarbituric acid-reactivity as diagnostic indices of lipid peroxidation and peroxidative tissue injury," Free Radical Biology \& Medicine, vol. 9, no. 6, pp. 515-540, 1990. 